\title{
God's spirit (of wisdom) has been sent into the world, not Covid-19: A contextual systematic-theological perspective
}

\section{Author: \\ Daniël P. Veldsman ${ }^{1}$ @ \\ Affiliation: \\ ${ }^{1}$ Department of Systematic and Historical Theology, Faculty of Theology and Religion, University of Pretoria, Pretoria, \\ South Africa}

Research Project Registration: Project Leader: D.P. Veldsman Project Number: 01224719

\section{Description:}

This research is part of the project, 'Religious Experience from an evolutionary perspective', directed by Prof. Dr Danie Veldsman, Department of Systematic and Historical Theology, Faculty of Theology and Religion, University of Pretoria.

Corresponding author: Daniël Veldsman, danie.veldsman@up.ac.za

Dates:

Received: 30 June 2020 Accepted: 26 Aug. 2020 Published: 26 Oct. 2020

How to cite this article: Veldsman, D.P., 2020, 'God's spirit (of wisdom) has been sent into the world, not Covid-19: A contextual systematic-theological perspective', HTS Teologiese Studies/Theological Studies 76(1), a6222. https://doi. org/10.4102/hts.v76i1.6222

\section{Copyright:}

(c) 2020. The Authors. Licensee: AOSIS. This work is licensed under the Creative Commons Attribution License.

\section{Read online:}

How are we to make theological sense of the Covid-19 pandemic? In response to the viewpoint of Wilhelm Jordaan as expressed in a popular newspaper that it is foolish to understand Covid-19 as God's punishment or nature's way for restoration, it is critically argued that Jordaan mostly helps us with what not to think, but not so much with what to think of the current situation from a Christian theological perspective. The theological perspective that is presented in response to Jordaan takes as the vantage point a different interpretative line of an image of God (as 'regretting/sorrow God') over against more popular and established lines of God images such as God the Almighty. It is argued that the different God image of a 'silent God' and the need for wisdom that is prompted by the image challenges us here and now with an invitation to take (self)responsibility for the Covid-19-pandemic before a silent (distanced) God.

Contribution: This article represents original systematic-theological reflection on the doctrine of God and anthropology within contemporary theology-science discourses. It focuses on a Christian biblical neglected God image of a 'regretting/sorrow God' (Genesis) in relation to embodied personhood within the current Covid-19 pandemic. It proposes a newly formulated understanding of a 'silent God' on the one hand and human self-responsibility and the seeking of wisdom on the other hand.

Keywords: Wilhelm Jordaan; wisdom; Covid-19 pandemic; a regretful/sorrow God; selfresponsibility.

\section{Introduction}

'Foolish to think' 1 that Covid-192 is either a punishment of God or nature's way to ensure renewed equilibrium writes the retired South African psychologist Wilhelm Jordaan (2020:1) in a popular newspaper's weekly column. Does Jordaan's remarks and judgement help us all to make sense of the worldwide corona pandemic that we are currently experiencing? There are a wide range of multifaceted questions flowing like an existential-social tsunami over individuals and societies from China to Europe to the Americas and Africa in their respective contextual quests of making (read: drinking) sense from their own life- and worldview-wells ${ }^{3}$. In my academic opinion, the best interpretative manner to approach and judge our 'thinking' and 'foolishness' in the current contexts will be a transversal approach. ${ }^{4}$ Various reasons in my opinion force us to take this

1.Jordaan (2020:1) concludes his short article with the following statement: 'Dis dwaas om so te dink' [translated: 'It is foolish to think that']. I take his concluding words as the vantage point in my engagement with him and for my choice as argumentative focus on wisdom (over against 'foolish').

2.COVID-19 is a disease caused by a new strain of coronavirus that appeared in 2019. 'CO' stands for corona. 'VI' stands for virus. 'D' stands for disease. '19' for the year of its origin. At its origination, it was labelled '2019 novel coronavirus' or '2019-nCoV'.

3.At the time of writing in June 2020, more than 200 countries have been affected and more than 500000 people have already died worldwide of the Covid-19 virus or related symptoms. In South Africa, the number of deaths was approaching 2500 . And the death to is still climbing. The journalist Willem Brümmer (2020) gives a very sober and insightful overview of the developments over the last 5 months since its outbreak, the efforts to curb the pandemic, the scientific thinking and presuppositions - often unmasked at a later stage as incorrect and misleading - behind the efforts, the wide-ranging uncertainties (vascular or pulmonary disease?), the mistakes (translation of 'bollemakiesies') that have been made and the little that we are sure of now.

4.Why the specific emphasis on transversal? The emphasis is to distinguish my approach from interdisciplinary and multi-disciplinary approaches (see Fuentes and Deane-Drummond (2018) for a very clear description of the differences between interdisciplinary and approaches (see Fuentes and Deane-Drummond (2018) for a very clear description of the differences between interdisciplinary and latter approaches seek to combine researchers from distinct disciplines that share their respective insights but seldom incorporate latter approaches seek to combine researchers from distinct disciplines that share their respective insights but seldom incorporate
them into their own worldviews. The biggest disadvantage of both these approaches is that they are thin on the integration of them into their own worldviews. The biggest disadvantage of both these approaches is that they are thin on the integration of
frameworks from different disciplines. They are therefore not that open on the broadening and deepening of a specific intellectual frameworks from different disciplines. They are therefore not that open on the broadening and deepening of a specific intellectual
approach. Fuentes and Deane-Drummond (2018:11-12) captures the specific contribution of transversal approaches well by explaining approach. Fuentes and Deane-Drummond (2018:11-12) captures the specific contribution of transversal approaches well by explaining It has the goal - and that is the most important advantage of the approach - of developing a relationship that creates the possibility for discourse in which the terms of all the participant disciplines are, or can be, expressed, thus facilitating the possibilities for intellectual transformation that is more thorough, intensive and generative than in inter-or multidisciplinary approaches. Transcending disciplinary boundaries enable the possibility of synthesising knowledge anew, and in my opinion, this is precisely what we need in addressing the current pandemic. 
approach as being the most responsible manner to address the multifaceted challenges that we are presently confronted with. The pandemic does not respect boundaries. The pandemic does not differentiate between political, ideological life- and world-views. The pandemic does not respond to or respect academic fields in isolation that are anxiously and fervently pursuing its medical obliteration and philosophical sense-making. But in its relentless ongoing destruction of human lives, it does have a preferential option and extremely strong claw for physical-emotional soft spots of human and societal vulnerabilities. And whilst we are sanitising and wearing masks as precaution for not getting infected, the pandemic is sanitising, on the one hand, our misplaced mindsets, behavioural patterns and disjointed or distorted relations, and on the other hand unmasking shallow and cheap answers to deep anthropological values and ideologies 5 . It unearths economic injustices, distorted and disconfirmed relationships (of power), and brutally exposes societal marginalisation. Whilst those infected struggle to breathe, it seems to us from our sense-making efforts as if the earth is sighing a breath of ecological relief. Whilst spreading its claws, the virus leaves no stone unturned: not even - if I may playfully but seriously employ a metaphoric image from a Christian perspective - the stone that has been rolled away after three days as message of resurrection, offering a renewed world of forgiveness, empathy, reconciliation, hope, faith and love. And to stay interpretatively in the historical vicinity of cross and resurrection imagery: As it crosses our hearts (and lungs) and societal paths, we are religiously left with only the cross of abandonment. Or not?

How are we to discern in these trying and unprecedented circumstances thinking (and to add: living full lives as embodied persons!) that is not foolish - as Jordaan's remark and personal judgement claims? How are we to find judgements that have integrity and are credible? I would like to critically argue that Jordaan only assists us with what not to think, but he does not really help us to constructively think what to think, that is: If it is then no punishment from God, how is God's involvement - if any? - to be understood? And: if this is then no correction from nature as Jordaan states, what is it then with nature? In my engagement with Jordaan's opinion regarding the punishment of God or nature's way to ensure renewed equilibrium, I will firstly briefly present his argument. Secondly, the question will be posed on why I am responding critically by saying that Jordaan's answer only helps us with what not to think but does not help us with what to think. Thirdly, a framework will be constructed for pursuing a theological direction in which I would like to venture beyond the 'foolishness' of only a negative response in a time in which we long to be positive, namely pursuing an emphasis on and perspective from the spirit of wisdom.

5.In a recent contribution to the journalTrouw, the Dutch philosopher Damiaan Denys (2020) (2020) emphs is a healthy corection to our megalome from the oring from the original Dutch. "Het coronavirus is een gezonde correctie op onze megalomane levenstijl'.). He goes further to call it a 'wake-up call from the Creator' (Dutch: '... een tik van de Scheppes')

\section{Jordaan's judgement of foolishness}

In his short exposition with the title, Covid-19-pandemic not sent by either God or nature, Jordaan argues from the vantage point that it is ridiculous ('slaan ' $n$ mens dronk') to think that God sent Covid-19 as punishment to humanity for not keeping the earth ('aardemishandeling') or that Covid-19 is the manner in which nature is restoring its balance to bring about equilibrium. He is appalled by the former as it understands God as a God of wrath. ${ }^{7}$ He asks the question: Why then not rather simply confess our dependence of a loving, embracing God in challenging times like these? The latter is more difficult (translation of 'tameletjie') to handle as judgement. Mother Earth will not allow her being abused and is therefore cross and will ensure restoration. Jordaan sees the judgement as an 'anthropomorphic mistake' as it takes being human as point of orientation and endows nature with human characteristics. We transpose in this manner, according to Jordaan, a human consciousness onto God and nature as if God and nature are like us and act like us. Created in the image of God (within the Christian tradition) most probably is responsible for the religious transposition of characteristics, but mistakenly it only produces a God made in the image of ourselves ${ }^{8}$. God's wrath only represents our sense of wrath. The very same anthropomorphic line of interpretation finds expression in our making sense of the patterns and rhythms in nature that we then subsequently describe by means of (symmetrical) mathematical calculations. Our mistake, in this instance, is to hold to a (anthropomorphic) view that nature 'manages' nature for the sake of cosmological order and her own restoration. Her affirmative action is one of punishment so that we can come to new insights that cosmic harmony and equilibrium can be restored - even if it implies the destruction of humans by means of a Covid-19 pandemic! For Jordaan - in short - it is foolish to think this way. But how are we then to rid ourselves from foolish thoughts on God and nature in coming to terms with the pandemic?

\section{Coming to terms: Exploring a possible and directional how?}

For the unlocking of the reality (especially in a period of lockdown!), we employ 'word-keys' and convictions that are concepts and insights with which we make sense of our experiences. ${ }^{9}$ Word-keys - to randomly name a few such as faith, God, being human as embodied personhood, punishment, patterns, evolution, et cetera - are deeply embedded in layered linguistic traditions and continuously find ongoing and new contextual expression. Our contextual articulation of these word-keys and our conceptual

6.The Afrikaans title is: 'Covid-19-siekte nie gestuur deur God of natuur nie'.

7.Jordaan (2020:1) refers in his exposition to Thomas More who described God as a 'frowning, punishing sour bulb' (translation of 'fronsende, bestraffende suurknol').

8.In his formulation, Jordaan echoes rightly the serious warning embedded in the words of Jean-Paul Sartre (1951:121): 'When God is silent, you can make him say whatever you want'.

9.In making sense of our experiences, we are continuously challenged in saying 'too little' or saying 'too much' with our word-keys on all phenomenon that evade empirical observation and control - such as consciousness and God, et cetera! 
organisation find expression in our interpretative sense-making of reality. The process or event of sensemaking eventuates into the formulation or perhaps more carefully described the (coherently) weaving together of theories. And the weaving is executed by means of language. What is of utmost importance, whether we are making sense of God, of ourselves or nature is that the nature of the language that we make use of, is metaphorical (apart from numerical or mathematical constructs). ${ }^{10}$ We therefore describe our experiential realities in an anthropomorphic ${ }^{11}$ manner by means of metaphors. ${ }^{12}$ Within the life world of being embodied persons, the metaphoric description unfolds contextually-existentially as double vision, that is, interpretatively looking and seeing the experienced realities from religious perspectives (Latin: perspicere, seeing through). We bind ourselves (Latin: religare - to bind, to tie) to - within a Christian tradition - the God who invites us to entrust our hearts and lives to Godself who has already relationally tied Godself to God's creation and creatures. It is a multidimensional invite deeply embedded in the historical documents over an extended period that tells in many and different ways $^{13}$ the stories of a God that is witness to as creator, provider, sustainer and saviour of God's creation and creatures. Stories that are widely embedded in the surrounding Near Eastern and Mediterranean world (add: of gods) of that time that find similar expressions within the Jewish and Christian message of God.

Who then is this God, ${ }^{14}$ who are we as creatures to understand the world, its purpose, ourselves before God, the meaning of life and personhood, salvation - and there are many more dimensions - but especially for the sake of this unfolding argument - God's ongoing involvement with God's creation and creatures who God created ex nihilo, ${ }^{15}$ that is, a God that created for no other reason outside of Godself than God's loving imagination.

10.See Van Huyssteen (1986) for a detailed exposition of the nature of religious language as metaphoric language. Van Huyssteen develops an insightful criticalrealistic model with three criteria, namely reality depicting, problem-solving ability and progress to determine the appropriateness of our religious language.

11.Anthropomorphic concepts of God dominate all God-talk from ancient times until today, even though the inadequacy of this 'humanizing' of God is generally admitted (cf Korpel \& De Moor 2011:60ff.).

12.The epistemological status of metaphoric descriptions - whether 'Black Hole' in cosmological reflection or 'God as shepherd' in theological reflection - do not differ.

13.The many and different ways refer to the rich variety of literary genres of the historical documents of the origin of Christianity, such as historical, prophetic, psalms, lament, parables to name but a few.

14.Although the exact etymological origin of the word God is uncertain, we do know that it represents a much later semantic development after the ancient JudaeoChristian manuscripts. Of all the many possibilities, I find especial affinity with the indication of a possible Indo-Germanic verb from the fifth-century Sanskrit tex with meanings (there are others as well) such as 'to invoke, to call upon' or 'to make light'. See for the wide-spectrum of possibilities on the origin of the word God for example: The Webster Dictionary; The Catholic Encyclopaedia; American Heritage Dictionary; Webster Revised Unabridged Dictionary; Oxford English Dictionary; American Heritage Dictionary.

15. Creatio ex nihilo (creation out of nothing) is traditionally explored in terms of matter (in conversation with Ancient Greek philosophy between Christians, NeoPlatonists and Gnostics), that is, whether God created from pre-existing (eternal) Platonists and Gnostics), that is, whether God created from pre-existing (eternal) matter, or simply from complete nihil fit, that is, nothing com 198-199). I deliberately avoid that debate and choose to focus on an interpretation of ex nihilo as 'nothing outside God' prompted God to create the world.

\section{A sorrow/regretting ${ }^{16}$ God and silence}

Within the rich and varied God-images from the historical documents of the Christian faith, ${ }^{17}$ I would like to take as vantage point a mostly ignored or neglected text ${ }^{18}$ on God's response after God's initial 'It is good' creation declarations, namely Genesis 6:6 (NIV):

The LORD regretted that he had made human beings on the earth, and his heart was deeply troubled.

And in NASB the translation reads:

The LORD was sorry that He had made man on the earth, and He was grieved in His heart.

What are we to make of the text? How does an image of a regretting, sorry God assists us in making sense of our faith relationship with God and God's relationship with the world $?^{19}$ If ever the famous short formulation of the task of theological reflection by the Italian Benedictine monk of the Catholic Church, Saint Anselm of Canterbury (1093-1109 $)^{20}$ poses a renewed deep challenge, it is now in our Covid-19 context and the question on God's involvement, and then from the perspective of a 'regretting' God. Anselm's formulation of the task of theological reflection reads:

Fides quaerens intellectum [Faith seeking understanding].

In what follows, I would like to pursue a contextual reformulation of Anselm's words, given our specific troubled context, namely Faith seeking wisdom. The two key words for the sake of my exposition are seeking and wisdom. Seeking, as firstly we honestly have to admit that we really do not know theologically what to make of the contemporary destructive pandemic, and secondly, the question can rightly be asked: Where is God in all that we are experiencing? It seems almost like after the horrific and traumatic circumstances of WW II - that God is silent (again). It was asked back then: Why did God not act, why did God not intervene to prevent such horrific human suffering? Is that also now perhaps the question to be asked anew in a time of traumatic social distancing on the silence of a God who is experienced as

16.The Hebrew word that is used is (vai.yin.na.chem) translated as "sorrow/ regretted'.

17.See McGrath (2017:175ff) for a good contemporary overview of the doctrine of God in which most traditional themes and images are explored and summarised. He states that contemporary concerns such as the rise of feminism, the suffering of the world and increased anxiety concerning the environment represent in the modern world the most important concerns. He raises the question and discussion of the impassibility and suffering of God, but not of a sorrow and regretful God. On of the impassibility and suffering of God, but not of a sorrow and regretful God. On respective implications.

18. My theological suspicion regarding the text as ignored or neglected has most probably to do with the easiness of making sense of a God that 'did not foresee' the outcome off a specific event. It interpretatively prompts a rethink of the dynamics of the God-human relationship.

19.This is not the only text in which we find a 'sorry/regretting' God. To mention a few other: God is sorry that He made Saul king (1 Sam 15:10), God is sick of the sacrifices of Israel (Is 1:11), God's Spirt was saddened by the uprising of His people (Is 63:10) and God weeps day and night over the affliction of his people (Jer 14: (Is 63:10);

20.For a brief discussion of Anselm and the context of the formulation of the phrase, see McGrath (2017:30-31). 
distant? In this argumentative context, it is to ask the question from the image of a 'sorry'/'regretting' God. Wisdom, as it represents in my opinion from an evolutionary perspective the best gift of engaging with our world that God has entrusted to us as Homo sapiens. But also, as Jordaan's accusation is one of 'foolishness', and within the biblical tradition, it is specifically wisdom that stands and is lauded over against 'foolishness'.

That God could be 'sorry/regretted' as has been formulated in Genesis, interpretatively implies a dynamic space and open relationship between God and God's creation. ${ }^{21}$ If this implication is translated into contemporary cosmological reflection, it prompts the impression that the holy God has created a universe (space) with a structural fine-tuned dynamic with an inherent physical-cosmological integrity and processes. ${ }^{22}$ But at the same (connected) time, created through processes of evolvement and emergence embodied persons who have been entrusted with imagination (the affective-cognitive anthropological fountain of being human) $)^{23}$ and with consequent entrusted deep responsibilities - not only to being creatures before God but also responsibilities towards creation. In this strong qualified sense of entrustment and responsibilities, a 'regretting/ sorrow' God has, respectively, to 'wait and see' what will happen next. ${ }^{24}$ Put differently: In God's loving imagination of creation and creatures, the most impressive and astounding values (such as love, justice, beauty, empathy, caring, etc.) and natural structures (such as laws of nature) unfolds but at the same time, the most daunting and challenging characteristics accompany creation (such as vulnerability, change and natural disasters). It simply implies freedom and bondage, good and bad, right and wrong, and order and disorder - and many more - are configuratively and

21 One of the most comprehensive studies on Divine Action that represents more than a decade of scientific-theological conferences (The Divine Action Project, 1988-2003) was sponsored by the Vatican Observatory and the Centre for Theology and the Natural Sciences (Berkeley). It is but one very comprehensive example of the complexity of and the unceasing fascination with the topic within the theology-science discourses.

22.Within the context of contemporary science-theology discourses, the nature of creation with regard to order and disorder, determination and indetermination on the one hand, and God's relationship and involvement represent one of the deepest challenges. Not only does the interaction between science and theology represent a first important hurdle to clear (i.e., how do we integrate scientific findings and theological convictions), a second major hurdle comes from the 'emotional messiness' of the debate because of 'playing off-sides' by both conversation partners in not respecting their own specific methodologies. Se Veldsman (2020) for a description on the 'emotional messiness' of the (the contempory tiscussion of Christian theology of instabi Gregersen and Görman (2002:86) states. What I find most illuminating an challenging is when Gregersen and Görman (2002:86) states 'it is distinctive fo religious language that the world as known by everyday language and by the specialised languages of the sciences are redescribed under the aspects of God's good creation and sinful distortion. For even though God is present everywhere in the cosmos - "in, with, and under," natural events of any sort - the purpose of God is not revealed everywhere'.

23.On the role and importance of affectivity in our faith relationship with God, see Veldsman (2014). The connection that is made between affectivity and wisdom literature in his exposition on the 'reasons of the heart' (Pascal) represents the background to the line of reasoning on a 'regretting' God.

24.Although the 'silent God' is only discussed in the next section, the words of Barbara Brown Taylor (1998:76) captures well the connection 'waiting - silence responsibility' that I will ultimately explore, namely 'The idea that God is patient, or that God "waits for" creation could, it would seem, allow the silence of God that grants responsibility to the world to be understood as coterminous with God's salvific action'. dynamically part and parcel of the very fibre of creation and creatures.

In the interpretive line with a 'regretting/sorry' God and the created spatial and relational openness and freedom follows the question: Is this then also the God who can be experienced as silent? What then is the connection between a 'sorry/ regretting' God and a silent God? And if, what does that mean?

The concept of silence and a silent God is extremely difficult to describe theologically as it first has to be interpreted (con) textually. ${ }^{25}$ The silent God is not in any way to be confused with the question on the existence or non-existence of God. And a silent God presupposes a God that has spoken before! ${ }^{26}$ Silence is also much more than simply the absence of sound ${ }^{27}$. The concept of a silent God is however nothing new. Especially after WWII, a vast corpus of literature came about in grappling deeply with the question of a silent God. ${ }^{28} \mathrm{I}$ can only reflect here briefly on some of the heart-gripping and interpretative-directional insights. I would like to join those discourses on the silent God that wrestle specifically with the biblical witnesses on the silent God.

The concept of 'silence' within the biblical literature unfolds as silence between humans, silence before God and the silent God (see Korpel \& De Moor 2011). Various reasons - such as offenses, awe or fear, forbearance or prudence, incapacity and sleeping - can be given for the silence, whether between humans or between humans and God. However, Korpel and De Moor (2011:238ff.) distinguishes between comprehensible divine silence and incomprehensible divine silence regarding the silent God. The latter, namely the incomprehensible divine silence, is of importance for me for the focus of my argument. How according to Korpel and De Moor could it be understood?

From their extensive study, they state:

According to both ancient Near Eastern sources and the Bible only the almighty Creator was able to break the primordial silence. Before he spoke, stillness reigned everywhere according to Egyptian theologians of the New Kingdom, Neo-Babylonian

25.In what follows, I gratefully acknowledge the contribution of The Silent God by Korpel and De Moor (2011) with which I strongly engage and make use of in my approach and understanding of the silent God.

26.Korpel and De Moor (2011:280) state: 'On what rational grounds does a person expect an answer from the deity to whom she or he turns? God cannot be "silent" if he does not "speak." He cannot "speak" if He does not "exist." Belief in a "silent" God presupposes at least the belief that he has spoken in the past and might speak again'.

27.Silence is indeed much more than the absence of sound as Tom Bruneau 2009:281ff.) explores within a science-theology context. He indicates that current brain studies show that silence does indeed exist as processes of traditional and religious practice and belief, as well as intrapersonal aspects of spirituality, contemplation, and meditation. According to him, such processes have been largely neglected or even negated in much of behavioural communication research as unimportant simply because silence seems elusive and measures are not apparent or are difficult. Bruneau (2009:281) concludes that to believe in deep silence '... is to believe in spirituality'.

28.Korpel and De Moor (2011) - to give but one example - have a very helpful extensive bibliography. Not only do they provide literature on the silent God in Modernity (Modern literature and media; some theologians and philosophers, and in agnosticism and atheism) but also of the silent God in terms of the biblical and in agnosticism and atheism) but also of the silent God in terms of the biblical
roots and world. Of special interest is also their contribution on the broader context of the Ancient Near East. 
wisdom texts and much later Hebrew sages. Even though they were deeply convinced of the Creator's absolute transcendence, they all assumed that he did listen to human complaints and would respond to their prayers. So they vented their deep disappointment if the remote deity remained silent. (Korpel \& De Moor 2011:274)

Looking at biblical examples, we find that many Psalms express the experiences of a silent God. Their responses to the silence however differ. We find deep disappointment especially if no reasons can be found for the experiences by the faithful of a silent God, that is, for incomprehensible divine silence:

How long wilt thou forget me, O Lord? For ever? How long wilt thou hide thy face from me? How long shall I take counsel in my soul, having sorrow in my heart daily? how long shall mine enemy be exalted over me? Consider and hear me, O Lord my God: lighten mine eyes ... (Ps 13:1-3 - KJV)

Except for the longing for a response from God, there is also a longing for an answer:

My God, my God, why have you forsaken me? Why are you so far from saving me, so far from my cries of anguish? 2 My God, I cry out by day, but you do not answer, by night, but I find no rest. (Ps 22:1-2 - NIV)

And except for the longing for a response and longing for an answer, there is also an engagement with God on the situation and outcome: ${ }^{29}$

To you, Lord, I call; you are my Rock, do not turn a deaf ear to me. For if you remain silent, I will be like those who go down to the pit. (Ps 28:1 - NIV)

In a similar vein, we find in the prophetic literature (Hab 1) an engagement with God and a human response of demanding a reply:

How long, Lord, must I call for help, but you do not listen? Or cry out to you, 'Violence!' but you do not save? (Hab 1:2 - NIV)

In a very interesting and fascinating twist in some biblical passages that I would like to combine with the preceding longings and pleas, the silence of God and the waiting for God becomes an invite and urge for action on the part of the one standing before God, the one longing and pleading for an answer and explanation from God. The silence communicates without words an invitation and urge to turn from being a vulnerable, fragile spectator and victim, to turn to be a participant, that is, to take action and responsibility for the situation! A few passages from the Old and New Testament must suffice.

In the book of Ruth, Naomi alias Mara (!) ${ }^{30}$ turns from bitter spectator and victim ('The Lord's hand has turned against me!' - Ruth 1:13) to a planning mother-in-law on behalf of

29.See also Psalm 83:2 (O God, do not keep silence; do not remain quiet and do not be still, O God! ) and Psalm 109:1 (Be not silent, O God of my praise).

30.See Ruth 1:20 where Naomi tells Ruth not to call het Naomi, but Mara as God has made her life very bitter. her Moabite daughter-in-law Ruth. In the prophetic literature, we find very similar situations and responses. I restrict myself to the following chapters from Isiah, namely Isaiah 40, 51, 52 and 59. In Isaiah 40, the way for the Lord must be prepared; a highway for God; their voices must be raised on behalf of the creator God; in Isaiah 51 and 52, the people of God is called upon to awake, shake off their chains and restore their own strengths. And even more astounding, God expresses in the words of the prophets wonder about the fact that nobody intervenes on his behalf when lawlessness is spreading like wildfire. The very same emphasis is qualified and elaborated on in the book of Amos, when it is stated that under the protection of God's hand the prophet's words become words of the Creator himself who wants to create new things. It is their Creator who reveals his ponderings to humanity - and he does that through his Spirit!

If I turn to examples in the New Testament to populate the argumentative line of 'not simply being a spectator' but a 'participant' in the movement of God in God's creation, one particular example stands out, namely Paul's (1 Cor 3) emphasis on people as God's 'fellow workers' (ESV; KJV), or God's 'labourers' (KJB) or 'co-workers' (NIV) of God's building:

According to the grace of God, which was given to me, as a wise master builder I have laid the foundation, and other builds on it. But let each one take heed how he builds on it. (1 Cor 3:10)

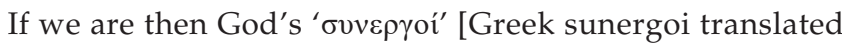
as fellow workers / co-workers], then the very same 'sorry/ regretting' God continues through the ages and up to now to respect God's own handiwork. Wisdom and discernment in our being of co-workers of God are indispensable and the best gifts that we have been entrusted with. And to assist us in being God's co-workers in discernment and wisdom, God has given us God's spirit through which - in the words of the Psalmist - we long and plea:

May the favour of the Lord our God rest on us; establish the work of our hands for us - yes, establish the work of our hands. (Ps 90:17 NIV)

The words of the Psalmist, their longing and pleas, the taking of responsibility for their situation as depicted in the prophetic literature, Paul's emphasis on people as God's co-workers and the importance of discernment and wisdom (as gift of God's spirit) ${ }^{31}$, all find a heart-gripping existential echo more than 20 centuries later in the aftermath of the

31.There are a broad spectrum of biblical literature on the gift and the role of the spirit of God in our lives. Some of the most profound and insightful texts, are: Isaiah 42:1 ('I will put my Spirit on him and he will bring justice to the nations' - NIV); Ezekie 11:19 'I will give them an undivided heart and put a new spirit in them; I will remove from them their heart of stone and give them a heart of flesh' - NIV); see also Ezekiel 36:26; Qoheleth 12:7 ('Then shall the dust return to the earth as it was: and the spirit shall return unto God who gave it' - KJV): See also Luke 11:13. John and the spirit shall return unto God who gave it' - KJV); See also Luke 11:13; John 7:39; Handelinge 2:38; Roman 5:5; 2 Korintus 1:22 ('Set his seal of ownership on us, and put his Spirit in our hearts as a deposit, guaranteeing what is to come' NIV); Galatians 3:2 ('I only want to learn this from you: Did you receive the Spirit by ( whe law or by believing what you heard?" - CSB), 2 Timothy 1:7; 1 Joh 3:24 ('Whoever keeps his commandments abides in God, and God in him. And by this we know that he abides in us, by the Spirit whom he has given us. And we know he lives in us because the Spirit he gave us lives in us'. - ESV). 
intense suffering of the Holocaust - and of the silence of God. One example that stands out for me must suffice. It is the example of the young Dutch woman Etty Hillesum (1914-1943) who was killed at the age of 29 in Auschwitz concentration camp. ${ }^{32}$

Just more than a year before her killing, she writes on the 12 July 1942 a Sunday morning prayer in which she longs and pleas before God:

Dear God, these are anxious times. Tonight for the first time I lay in the dark with burning eyes as scene after scene of human suffering passed before me. I shall promise You one thing, God, just one very small thing: I shall never burden my today with cares about my tomorrow, although that takes some practice. Each day is sufficient unto itself. I shall try to help You, God, to stop my strength ebbing away, though I cannot vouch for it in advance. But one thing is becoming increasingly clear to me: that You cannot help us, that we must help You, God, in ourselves. And perhaps in others as well. Alas, there doesn't seem to be much You Yourself can do about our circumstances, about our lives. Neither do I hold You responsible. You cannot help us, but we must help You and defend Your dwelling place inside us to the last. (Quoted in Korpel \& De Moor 2011:287)

By means of Etty's words, I would like to interpretatively weave together the preceding argumentative line of the human response to the silent God. So much can be said and made of her experience and the manner in which she expressed her experience of God. The following short summarising remark however must suffice. If God then is experienced as silent, we as the faithful before God must speak here and now to the situation we find ourselves in. If it is inevitable that people suffer, God himself may well be speechless for sorrow and regret, and God's inability to do something about it (cf Korpel \& De Moor 2011:288). God's very silence communicates without words an invitation to us to accept in discernment and wisdom ${ }^{33}$ that we have to act on 'God's behalf', as the very (S)pirit that helped the biblical authors to say 'God said', 'God asks of us' and 'Abba' is still the very same (S)pirit that we can depend on as accompanying creative voice or force to guide us in wisdom and to plea before a silent God to have mercy on us under these Covid-19 circumstances. $^{34}$

32.Esther 'Etty' Hillesum was the Dutch author of confessional letters and diaries, which describe both her religious awakening and the persecutions of Jewish people in Amsterdam during the German occupation. Her diaries record the increasing anti-Jewish measures imposed by the occupying German army and the growing uncertainty about the fate of fellow Jews who had been deported by growing uncertainty about the fate of fellow Jews who had been deported by
them. In addition to forming a record of oppression, her diaries describe her them. In addition to forming a record of oppression, her diaries describe her
spiritual development and deepening faith in God. See Wikipedia https://en. spiritual development and deepen
wikipedia.org/wiki/Etty_Hillesum

33.I can relate well with the insightful description by Fuentes and Deane-Drummond (2018:1) of wisdom in evolutionary anthropology. Fuentes states that 'wisdom is often defined as the pattern (and ability) of successful complex decision-making in navigating social networks and dynamic niches in human communities'. Closely related to their description, and in opposition to 'folly' ('foolishness'), the Oxford English Dictionary in its definition of wisdom emphasises the 'capacity of judging rightly in matters relating to life and conduct'.

34. Rachel Muers (2004:94ff.) makes the same point: The gift of the Holy Spirit is the gift both of the promise that God will hear and of the 'capacity for discernment and recognition' that accords with God's own act of discernment and recognition. The possibility of inner worldly transformation depends on both these gifts - being possibility of inner worldly transformation depends on both these gifts - being
freed for responsible action before God and being enabled to understand the freed for responsible action bef
complexity of penultimate reality.

\section{Beyond foolishness: The wisdom of love (of helping God out)}

The vulnerable path on which we find ourselves as fragile embodied persons is to acknowledge at first that we are deeply challenged in making theological sense of our contemporary experiences - and simply do not have easy, ready answers and/or know what is the purpose (or purposelessness) of facing (with masks) the Covid-19 pandemic in God's good creation. It is relentless and ruthless. Does that imply that we currently have to come to terms with abandonment and silence before a closed sky? No. God has spoken before into our reality in many different ways and over an extended period of time, but especially in the cross and resurrection of Jesus Christ as witnessed in the biblical literature. The cross of Jesus Christ symbolically stands - interpreted from a theology-science context - for all suffering, pain, injustices, distorted relationships, disasters, tragedies, oppression, marginalisations, deep disappointments (and surely not only for our sins!) that life offers and eventuates but also for the immense trauma of the Covid-19 pandemic. And the significance of the cross in its dialectical connectedness with the witness of a resurrection opens up (and invites) new possibilities for life and living - and hope. What new life possibilities? Hope? Having acknowledged our not knowing before a silent God who has spoken before, we will have to stand up $^{35}$ and take full responsibility for seeking wisdom in 'helping out' our God who may be speechless for sorrow and regret. It is the very same creator God (of Gn 6:6) who has created all that came forth from God's loving imagination. The same God who has spoken into the cross and resurrection of Jesus Christ. The same God who has sent God's spirit into the world to make real that which God in Jesus Christ has made possible. The same God who has sent God's spirit into the world, not Covid-19. Covid-19 is not - as Jordaan rightly contested an expression of God's wrath. But then to move now beyond 'foolish' thinking with which Jordaan did not help us. ${ }^{36}$ As embodied persons who have been entrusted with God's spirit, we should pursue with all our hearts and all our means, that is, with all possible human measures to fight the virus 'on God's behalf' and 'defending God's dwelling place' (Hillesum) in bringing healing and restoration to all of God's creatures and to nature. In this manner, we as Homo sapiens [Latin for 'wise man' - sic!] who has been created in the image of God and who has been endowed with God's spirit, can wholeheartedly and passionately pursue responsibly in discernment both the love for wisdom (in all our scientific efforts together) 35. In Afrikaans, there is a much stronger wordplay, which i tried to capture in my
English formulation, namely Ons sal opstandig moet lewe en die lewe se uitdaginge aanpak!

36.What follows as conclusion is my making hermeneutical-contextual sense (as reinterpretation) of the gripping text of Ephesians 3:14-20 as prayer for spiritual strength: 'for this reason I bow my knees before the Father, from whom every family in heaven and on earth is named, that according to the riches of his glory he may grant you to be strengthened with power through his Spirit in your inner may grant you to be strengthened with power through his Spirit in your inner being, so that Christ may dwell in your hearts through faith - that you, being rooted and grounded in love, may have strength to comprehend with all the saints what is the breadth and length and height and depth, and to know the love of Christ that surpasses knowledge, that you may be filled with all the fullness of God. Now to him who is able to do far more abundantly than all that we ask or think according to the power at work within us, to him be glory in the church and in Christ Jesus throughout all generations, forever and ever. Amen' (ESV). 
and the wisdom of love (i.e. in empathy, caring and compassion) in the survival fight against the Covid-19 pandemic and addressing the unmasked injustices and marginalisations.

\section{Acknowledgements Competing interests}

The author declares that he has no financial or personal relationship(s) that may have inappropriately influenced him in writing this article.

\section{Author's contribution}

The author declares that he is the sole author of this research article.

\section{Ethical consideration}

This article followed all ethical standards for a research without direct contact with human or animal subjects.

\section{Funding information}

The author received no financial support for the research, authorship and/or publication of this article.

\section{Data availability statement}

Data sharing is not applicable to this article, as no new data were created or analysed in this study.

\section{Disclaimer}

The views and opinions expressed in this article are those of the author and do not necessarily reflect the official policy or position of any affiliated agency of the author.

\section{References}

Brümmer, W., 2020, '5 Maande later: Dit is wat ons nou van virus weet', Netwerk24 26 Junie 2020, viewed 26 June 2020, from https://www.netwerk24.com/stemme/ aktueel.

Bruneau, T., 2009, 'Silence, silences, and silencing', in S.W. Littlejohn \& K.A. Foss (eds.), Encyclopedia of communication theory, vol. 2, pp. 880-884, SAGE, London.

Denys, D., 2020, 'Tien geboden', Trouw, 04 April 2020, viewed 28 May 2020, from https://www.trouw.nl/leven/filosoof-damiaan-denys-het-coronavirus-is-eengezonde-correctie-op-onze-megalomane-levensstijl.

Hillesum, E., viewed 28 June 2020, from https://en.wikipedia.org/wiki/Etty_Hillesum.

Fuentes, A. \& Deane-Drummond, C., 2018, Evolution of wisdom: Major and minor keys, Center for Theology, Science, and Human Flourishing, University of Notre Dame, Notre Dame.

Gregersen, N.H., 2020, 'The corona crisis unmasks prevailing social ideologies (editorial)', Dialog 2020, pp. 1-3, Wiley, viewed 29 May 2020, from onlinelibrary. com/journal/dial.

Gregersen, N.H. \& Görman, U. (ed.), 2002, Design and disorder: Perspectives from science and theology, T\&T Clark, London.

Jordaan, W. 2020 'Covid-19-siekte nie gestuur deur God of natuur', Netwerk24, 29 April 2020, viewed 29 April 2020, from https://www.netwerk24.com/menings.

Korpel, M. \& De Moor, J., 2011, The silent God, Brill, Leiden.

McGrath, A., 2017, Christian theology, John Wiley \& Sons, Oxford.

Muers, R., 2004, Keeping God's silence: Towards a theological ethics of communication, Blackwell, Oxford.

Sartre, J.-P., 1951, Le diable et le bon Dieu: Trois actes et onze tableaux, Gallimard, Paris. Taylor, B.B., 1998, When God is silent, Cowley Publications, Lanham.

Van Huyssteen, W., 1986, Teologie as kritiese geloofsverantwoording, RGN, Pretoria.

Veldsman, D., 2014, 'With reasons of the heart before God. On religious experience from an evolutionary-theological perspective', NGTT 55(1-2), 425-441. https:// doi.org/10.5952/55-1-2-534

Veldsman, D., 2020, 'Science', in B. Agang, D.A. Forster \& H.J. Hendriks (eds.), African public theology, pp. 175-187, Langham Publishing, Carlisle. 